Special issue of the International Conference on Computational and Experimental Science and Engineering (ICCESEN 2014)

\title{
Measurements of Radon Content in the Thermal Waters in Sakarya
}

\author{
F. ErtuĞral*, H. Yakut, E. Tabar, R. Akkaya, N. Demirci and Z. Zenginerler \\ Sakarya University/Physics Department, Sakarya, Turkey
}

\begin{abstract}
The paper presents the results of radon concentration measurements in thermal waters of Kuzuluk and Taraklı (Sakarya, Turkey) and their contribution to annual effective dose exposure. The radon measurements were performed using RAD 7, a solid state $\alpha$ detector, with RAD $\mathrm{H}_{2} \mathrm{O}$ accessory. The results show that the radon activities are within the range of $0.19-5.89 \mathrm{Bql}^{-1}$ with an average value of $0.98 \mathrm{Bql}^{-1}$. The associated annual effective doses have been estimated to range from 0.14 to $0.40 \mu \mathrm{Svy}^{-1}$ for ingestion and from 1.81 to $5.14 \mu \mathrm{Svy}^{-1}$ for inhalation of radon released from the water. These values are significantly lower than the WHO recommended limit of $100 \mu \mathrm{Svy}^{-1}$
\end{abstract}

DOI: 10.12693/APhysPolA.128.B-251

PACS: $29.40+\mathrm{n}$

\section{Introduction}

Radon ${ }^{222} \mathrm{Rn}$ () is an alpha-emitting, colorless, odorless, radioactive noble gas produced naturally in the environment by the decay of radium in uranium decay chain $[1,2]$. It is well known that some geothermal waters can have high concentrations ${ }^{222} \mathrm{Rn}$ [3]. These waters are used in thermal spas where therapy is carried out and generally $70 \%$ of radon in water is released to the indoor air [4]. Thus, the exposure of radon and its short-lived decay products namely, ${ }^{218} \mathrm{Po}$ and ${ }^{214} \mathrm{Po}$, present in spa facilities can reach elevated values [5]. The exposure of person to high concentration of ${ }^{222} \mathrm{Rn}$ and its progeny for a long period leads to health problems, particularly lung cancer, resulting from inhalation of radon [6]. However, a very high level of radon in ingested drinking water can also leads to a significant risk of stomach cancer [7]. Because of its potential health hazard, radon level in thermal waters and associated effective doses have been documented in many regions worldwide for decades [5, 8-10] and also led to extensive surveys in Turkey [11-15]. In the present study, the radon contents of thermal waters located in Kuzuluk and Taraklı regions of Sakarya were measured and the results were evaluated according to international recommendations.

\section{Experimental details}

Radon concentration measurements were performed in selected five thermal waters in Kuzuluk and Taraklı during a period of time between March 2014 and September 2014. Kuzuluk and Taraklı are well-known geothermal areas in Turkey. They lie on tectonically active North Anatolian Fault Line and its branched sub-faults.

*corresponding author; e-mail: ertugral@sakarya.edu.tr
The thermal springs in area are controlled by these fracture patterns. The hot springs in the area are used for physical therapy and drinking purposes by visitors.

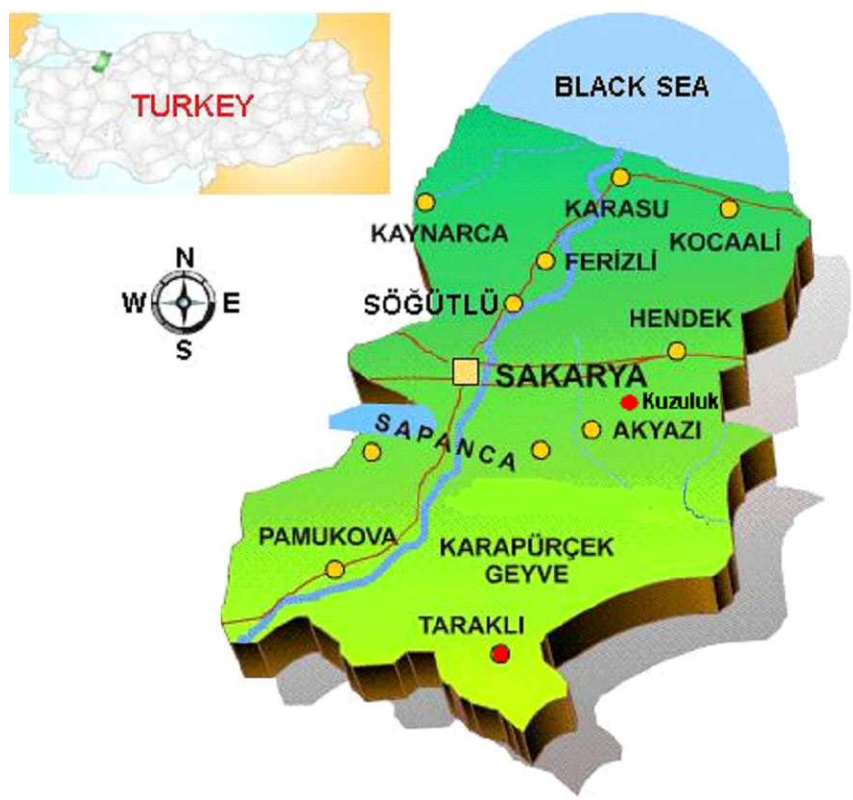

Fig. 1. Location of Sakarya in map of Turkey.

${ }^{222} \mathrm{Rn}$ concentrations in thermal waters were measured using RAD 7, an electronic radon detector (Durridge Company Inc.), connected to a $\mathrm{RAD} \mathrm{H}_{2} \mathrm{O}$ (radon in water) accessory. Before the sampling, approximately $5 \mathrm{l}$ of water was let out. Then, the water samples were collected in special glass bottles (250 ml capacity). In laboratory, the bottles were connected to the RAD 7 and the internal air pump of it was used for purging radon from the water into the air-loop. The pump runs for $5 \mathrm{~min}$, aerating the sample (Fig. 2) and delivering the radon to the RAD 7. The system waits a further 5 min and then it starts counting. After $5 \mathrm{~min}$, it print out a short-form 


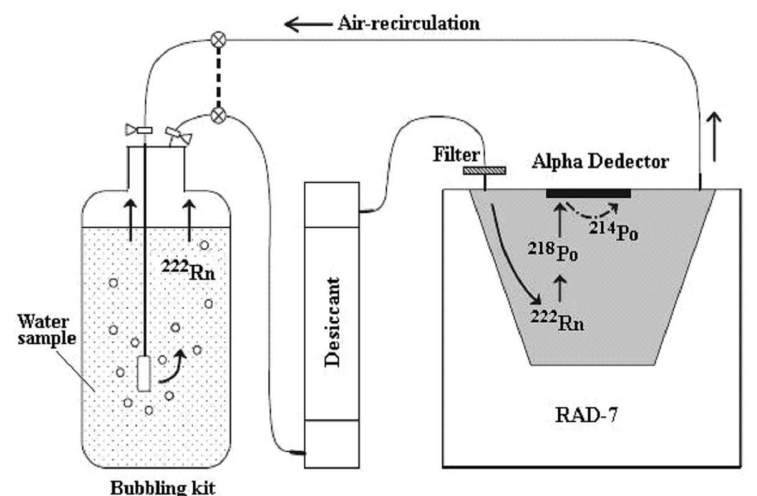

Fig. 2. Schematic diagram of $\mathrm{RAD} \mathrm{H}_{2} \mathrm{O}$ assembly.

report including the radon activity (in $\mathrm{Bql}^{-1}$ ) in water. The same things repeat again for 5 min later and for two more 5-min periods after that [16].

The annual effective dose due to ingestion of radon is calculated using the relation [2]:

$$
D_{\text {ing }}^{\mathrm{Rn}}=C_{\mathrm{Rn}} I_{\mathrm{a}} D_{\mathrm{f}},
$$

here $C_{\mathrm{Rn}}$ is the radon concentration of ingested water in terms of $\mathrm{Bql}^{-1}, I_{\mathrm{a}}$ describes the annual intake of drinking water $\left(60 \mathrm{ly}^{-1}\right)$ and $D_{\mathrm{f}}$ refers to dose conversion factor, $3.5 \times 10^{-3} \mu \mathrm{SvBql}^{-1}$. The dose contribution arising from the release of ${ }^{222} \mathrm{Rn}$ in water to the air is calculated using the relation [2]:

$$
D_{\text {inh. }}^{\mathrm{Rn}}=C_{w}^{\mathrm{Rn}} R_{w} F T D_{\mathrm{f}},
$$

where $C_{w}^{\mathrm{Rn}}\left(\right.$ in $\mathrm{Bqm}^{-3}$ ) is the radon concentration in water, $R_{w}$ is the ratio of radon in air to the radon in water $\left(10^{-4}\right), T$ is the average indoor occupancy time per person $\left(7000 \mathrm{hy}^{-1}\right), F$ is the equilibrium factor between radon and its progenies (0.4), and $D_{\mathrm{f}}$ is a dose conversion factor $\left(9 \mathrm{nSv} \mathrm{h}{ }^{-1} \mathrm{~Bq}^{-1} \mathrm{~m}^{3}\right)$ [2].

\section{Results and discussions}

The results of ${ }^{222} \mathrm{Rn}$ measurements in thermal waters of Sakarya have been represented in Fig. 3. The radon levels in the measured thermal waters varied between $0.19 \mathrm{Bql}^{-1}$ and $5.89 \mathrm{Bql}^{-1}$ with an average value of $0.98 \mathrm{Bql}^{-1}$. The lowest ${ }^{222} \mathrm{Rn}$ concentration $\left(0.19 \mathrm{Bql}^{-1}\right)$ was recorded in Kuzuluk 3 thermal water, while the highest level $\left(5.89 \mathrm{Bql}^{-1}\right)$ was measured in Tarakl 2 thermal water. The high value of radon measured in August and September in Tarakl 2 station may be due to the seismic events which cause rise in the emanation coefficient of radon from the rocks [17]. Geologically, Kuzuluk and Tarakl located on tectonically active North Anatolian Fault Line and its branched subfaults. The relations between the variations of radon concentration in water and the seismic activities have been documented in some studies [18].

In Table the ${ }^{222} \mathrm{Rn}$ contents in five thermal waters monitored in Sakarya and associated annual effective doses have been compared with those reported by other

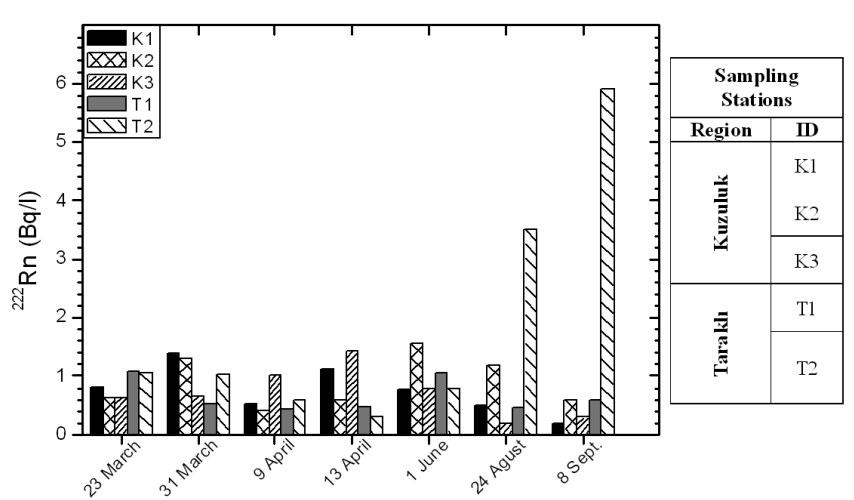

Fig. 3. The results of ${ }^{222} \mathrm{Rn}$ measurements in thermal waters of Sakarya.

\section{TABLE}

The comparison of ${ }^{222} \mathrm{Rn}$ activities and associated annual effective doses (last line, slanted) with other results.

\begin{tabular}{|c|c|c|c|c|}
\hline \multirow{2}{*}{$\begin{array}{c}222 \mathrm{Rn} \text { act. } \\
{\left[\mathrm{Bql}^{-1}\right]}\end{array}$} & \multicolumn{2}{|c|}{ AED $\left[\mu \mathrm{Svy}^{-1}\right]$} & \multirow{2}{*}{ Ref. } & \multirow{2}{*}{ Country } \\
\hline & ingestion & inhalation & & \\
\hline $7.7-506.2$ & - & - & {$[5]$} & Italy \\
\hline $1-560$ & $0-4200$ & - & [8] & Venezuela \\
\hline $145-2731$ & 3230 & - & [9] & Iran \\
\hline $24.5-648$ & $450-4700$ & - & [10] & Serbia \\
\hline $2.513-82.553$ & - & - & {$[14]$} & $\begin{array}{l}\text { Bursa, } \\
\text { Turkey }\end{array}$ \\
\hline $0.14-5.77$ & - & - & [13] & $\begin{array}{c}\text { West Anatolia, } \\
\text { Turkey }\end{array}$ \\
\hline $0.11-0.71$ & - & $0.28-1.78$ & {$[15]$} & $\begin{array}{l}\text { Amasya, } \\
\text { Turkey }\end{array}$ \\
\hline $0.3-31$ & 1.75 & - & {$[12]$} & $\begin{array}{l}\text { Dikili, } \\
\text { Turkey }\end{array}$ \\
\hline $0.21-5.82$ & $0.2-0.75$ & $2.44-9$ & {$[11]$} & $\begin{array}{l}\text { Yalova, } \\
\text { Turkey }\end{array}$ \\
\hline $0.19-5.89$ & $0.14-0.40$ & $1.67-4.74$ & & $\begin{array}{l}\text { Sakarya, } \\
\text { Turkey }\end{array}$ \\
\hline
\end{tabular}
Water type - thermal.

works. As can be seen from Table, radon levels recorded in the present study are relatively low when they are compared to corresponding radon activity measured in Italy [5], in Venezuela [8], in Iran [9], in Serbia [10] and also is lower than those reported from other parts of Turkey namely Dikili [12] and Bursa [14], but comparable to radon levels reported from Yalova [11] and from West Anatolia [13]. It is interesting to note that both of Yalova and Sakarya lie on North Anatolian Faulth Zone. Besides, the geological feature of Western Anatolia characterised by the near convergence of active fault systems are the same as Sakarya and Yalova regions. The activity concentrations of thermal waters measured in this study is slightly higher than those reported from Amasya [15]. On the other hand, there are geothermal aquifers where radon activity can reach higher levels than our results [9]. 
The annual effective doses range from 0.14 to $0.40 \mu \mathrm{Svy}^{-1}$ for ingestion of radon in water and from 1.81 to $5.14 \mu \mathrm{Svy}^{-1}$ for inhalation of radon released from the water. In addition, the total average annual effective dose was estimated to be $2.69 \mu \mathrm{Svy}^{-1}$. These values are well below the reference level of $100 \mu \mathrm{Svy}^{-1}$ recommended by WHO [19].

\section{Conclusion}

The first results of radon measurements in thermal springs of Kuzuluk and Taraklı basin were presented. The annual effective doses from ingestion and inhalation of radon were estimated and the contributions of radon isotope to the exposure of people who use the spa waters for therapeutic purpose were assessed. The total annual effective doses determined in this study are well below the total indicative dose of $100 \mu \mathrm{Svy}^{-1}$ suggested by WHO [19] for all groups of the population. Thus, radon present in thermal waters of Sakarya does not pose any significant health risk to the public.

\section{Acknowledgments}

This work was supported by Research Fund of the Sakarya University. Project Number: 2012-02-02-007

\section{References}

[1] H.Yakut, E. Tabar, Z. Zenginerler, N. Demirci, F. Ertugral, Radiat. Prot. Dosim. 157, 397 (2013).

[2] UNSCEAR Report, United Nations Scientific Committee on the Effects of Atomic Radiation Sources and Effects of Ionizing Radiation, 2000.

[3] C. Rodenas, J. Gomez, J. Soto, F. Maraver, J. Radioanal. Nucl. Ch. 77, 625 (2002).

[4] D. Desideri, M.R. Bruno, C. Roselli, J. Radioanal. Nucl. Ch. 261, 37 (2004).
[5] A. Bertolo, C. Bigliotto, Radiat. Prot. Dosim. 111, 355 (2004).

[6] R.C. Ramola, V.M. Choubey, M.S. Negi, Y. Prasad, G. Prasad, Radiat. Meas. 43, 98 (2008).

[7] A. Binesh, S. Mohammadi, A.A. Mowlavi, P. Parvaresh, Int. J. Water Res. Environ. Eng. 2, 174 (2010).

[8] A.D. Horvath, L.O. Bohus, F. Urbani, G. Marx, A. Piroth, E.D. Greaves, J. Environ. Radioactiv. 47, 127 (2000).

[9] M. Beitollahi, M. Ghiassi-Nejad, A. Esmaeli, R. Dunker, Radiat. Prot. Dosim. 123, 505 (2007).

[10] J. Nikolov, N. Todorovic, P.T. Petrovic, S. Forkapic, D. Mrdja, I. Bikit, M. Krmar, M. Veskovic, Radiat. Meas. 47, 443 (2012).

[11] E. Tabar, H. Yakut, J. Radioanal. Nucl. Ch. 299, 311 (2014).

[12] E. Tabar, M.N. Kumru, M.M. Sac, M. Ichedef, M. Bolca, F. Ozen, Radiat. Phys. Chem. 91, 89 (2013).

[13] F.S. Erees, G. Yener, M. Salk, O. Ozbal, Radiat. Meas. 41, 354 (2006).

[14] O. Gurler, U. Akar, A. Kahraman, Fresen. Environ. Bull. 19, 3013 (2010).

[15] F. Oner, I. Yigitoglu, H.A. Yalim, Radiat. Prot. Dosim. 157, 221 (2013).

[16] $\mathrm{RAD} \mathrm{H}_{2} \mathrm{O}$ accessory owner's manual, Durridge Company.

[17] D. Amrani, D.E. Cherouati, M.E.H. Cherchal, J. Environ. Radioactiv. 51, 173 (2000).

[18] H.A. Yalim, A. Sandıkcıoglu, O. Ertugrul, A. Yıldız, J. Environ. Radioactiv. 110, 7 (2012).

[19] Guidelines for third edition recommendations drinking-water quality, World Health Organization (WHO), vol. 1, Geneva 2008. 